\title{
ANALISIS PENGARUH PENGELUARAN PEMERINTAH DI SEKTOR PENDIDIKAN DAN KESEHATAN TERHADAP PENGENTASAN KEMISKINAN MELALUI PENINGKATAN PEMBANGUNAN MANUSIA DI PROVINSI JAWA TENGAH
}

\author{
Adi Widodo', Waridin², dan Johanna Maria K. ${ }^{2}$ \\ ${ }^{1}$ BPKP Perwakilan Jawa Tengah \\ ${ }^{2}$ Fakultas Ekonomika dan Bisnis Universitas Diponegoro Semarang \\ E-mail: maswhied@gmail.com
}

Diterima 6 Mei 2011/Disetujui 14 Juni 2011

\begin{abstract}
The purposes of this paper are (a) to illustrate patterns of development of not only public expenditures on education and health sectors, indicators of human development, and poverty indicators in Central Java province, (b) to identify and analyze the role of the Human Development Index (HDI) with regards to the relationship between government spending for education and health sectors and poverty reduction in the province: whether the HDI as a moderator variable or intervening variable. The data used were government expenditures in education and health sectors, HDI and regional poverty rates in 35 districts / cities in Central Java, in the period of 2007 to 2008. The study suggests that (a) in general, in the year 2007 and 2008, government spending patterns in education and health sectors, HDI and the percentage of the number of poor in the regencies / cities demonstrated a positive trend. That is, the increase in government spending on education and health sectors was followed by not only an increase in HDI but also by a decrease in the percentage of the population is the poor. Interestingly, the study suggests that HDI was more dominant to be a "pure moderator" variable rather than to be an intervening variable. This infers that the relationship between government spending on education and health sectors and the alleviation of poverty is reinforced by the role of HDI. Consequently, government spending on education and health sector did not by itself affect the poverty reduction directly.
\end{abstract}

Keywords: Human Development Index (HDI), government spending, education and health sectors, the poor

Pelaksanaan kebijakan otonomi daerah dan desentralisasi fiskal didasarkan pada pertimbangan bahwa daerahlah yang lebih mengetahui kebutuhan dan standar pelayanan bagi masyarakat di daerahnya, sehingga pemberian otonomi daerah diharapkan dapat memacu peningkatan kesejahteraan masyarakat di daerah melalui peningkatan pertumbuhan ekonomi. Adanya peningkatan dana desentralisasi yang ditransfer pemerintah pusat setiap tahunnya diharapkan dapat mendorong peningkatan laju pertumbuhan ekonomi. Laju pertumbuhan ekonomi daerah dipengaruhi secara positif dan signifikan oleh pembangunan manusia. Pada hakekatnya pembangunan adalah pembangunan manusia, sehingga perlu diprioritaskan alokasi belanja untuk keperluan ini dalam penyusunan anggaran (Priyo Hari Adi, 2009). Prioritas belanja dalam rangka peningkatan pembangunan manusia akan meningkatkan pula tingkat kesejahteraan masyarakat. Peningkatan pembangunan manusia dapat dicermati dari besar kecilnya IPMnya. Apabila IPMnya mengalami peningkatan, maka dapat diduga bahwa tingkat kesejahteraan masyarakat juga akan mengalami peningkatan. Jika tingkat kesejahteraan masyarakat meningkat, pada gilirannya penduduk miskin menjadi semakin berkurang baik dari segi jumlah maupun kualitasnya.

Kinerja pembangunan ekonomi Indonesia dalam beberapa tahun ini, secara umum dapat di- 
katakan sangat membanggakan dengan tingkat pertumbuhan ekonomi selama beberapa dekade terakhir ini sangatlah tinggi, walaupun mengalami penurunan di masa krisis. Tetapi tingkat pertumbuhan yang tinggi tersebut masih menyisakan sejumlah persoalan diantaranya kemiskinan dan rendahnya pembangunan manusia. Secara umum, selama periode 2007 - 2009, persentase penduduk miskin di Indonesia masih relatif cukup signifikan, meskipun mengalami penurunan selama periode 2007 - 2009, yaitu masing - masing secara berurutan mencapai 16,58 persen, 15,42 persen, dan 14,15 persen. Secara khusus, penurunan ini juga tercermin pada penurunan prosentase penduduk miskin di 6 provinsi di Jawa pada periode yang sama, yaitu masing - masing sebesar 14,44 persen di tahun 2007, menurun menjadi 13,59 persen di tahun 2008 dan 12,48 persen di tahun 2009. (Data dan Informasi Kemiskinan BPS, 2009)

Jika dilihat per provinsi yang ada di Pulau Jawa, di tahun 2009 terdapat 3 provinsi yang jumlah penduduk miskinnya di atas 1 juta jiwa, yaitu Provinsi Jawa Timur dengan jumlah penduduk miskin sebanyak 6,022 juta jiwa, Provinsi Jawa Tengah dengan jumlah penduduk miskin sebanyak 5,725 juta jiwa, dan Provinsi Jawa Barat dengan jumlah penduduk miskin sebanyak 4,983 juta jiwa. Provinsi Jawa Tengah secara berurutan dari tahun 2007 sampai dengan 2009 persentase penduduk miskinnya mencapai 20,43 persen, 19,23 persen, dan 17,72 persen. Walaupun menunjukkan kecenderungan yang menurun, namun Provinsi Jawa Tengah pada tahun 2009 menduduki peringkat pertama dalam hal persentase penduduk miskin jika dibandingkan dengan 5 provinsi lainnya di Pulau Jawa. Selain itu, selama kurun waktu tiga tahun dari tahun 2007 sampai dengan 2009, ternyata persentase penduduk miskin di Provinsi Jawa Tengah selalu paling tinggi jika dibandingkan dengan lima provinsi lainnya yang ada di Pulau Jawa.

Di samping dihadapkan pada angka kemiskinan yang cukup tinggi, Indonesia juga menghadapi masalah lain yang sangat serius, yaitu masih rendahnya kualitas SDM yang tercermin dari IPM atau dikenal dengan Human Development Index (HDI) yang dikeluarkan oleh United Nations Development Programme (UNDP).

IPM merupakan salah satu cara untuk mengukur taraf kualitas fisik dan non fisik penduduk. Kualitas fisik tercermin dari angka harapan hidup; sedangkan kualitas non fisik (intelektualitas) melalui laman- ya rata-rata penduduk bersekolah dan angka melek huruf; dan mempertimbangkan kemampuan ekonomi masyarakat yang tercermin dari nilai purcashing power parity index (PPP).

Pada tahun 2004, menurut BPS, capaian IPM Indonesia sebesar 68,70 dan pada tahun 2008 sebesar 71,17 , sehingga selama kurun waktu 4 tahun terjadi peningkatan IPM sebesar 3,60 persen. Demikian juga dengan kondisi IPM di Pulau Jawa, di mana secara nasional capaian IPM Provinsi Jawa Tengah pada tahun 2008 sebesar 71,60 dan Provinsi Jawa Tengah menduduki peringkat ke-14 jika dibandingkan dengan provinsi lainnya di Indonesia. Namun jika dibandingkan dengan 5 provinsi lainnya yang ada di Pulau Jawa, capaian IPM Provinsi Jawa Tengah pada tahun 2008 menduduki peringkat ke-3. Secara umum, capaian IPM seluruh provinsi di Indonesia termasuk provinsi di Pulau Jawa mengalami peningkatan dari tahun ke tahun. (BPS, 2009)

Pembangunan manusia merupakan salah satu indikator bagi kemajuan suatu negara. Suatu negara dikatakan maju bukan saja dihitung dari pendapatan domestik bruto saja tetapi juga mencakup aspek harapan hidup serta pendidikan masyarakatnya. Hal ini sejalan dengan paradigma pembangunan yang berkembang pada tahun 90-an yaitu paradigma pembangunan yang berpusat pada manusia (human centered development). Secara konsep, pembangunan manusia adalah upaya yang dilakukan untuk memperluas peluang penduduk untuk mencapai hidup layak, yang secara umum dapat dilakukan melalui peningkatan kapasitas dasar dan daya beli. Pada tataran praktis peningkatan kapasitas dasar adalah upaya meningkatkan produktivitas penduduk melalui peningkatan pengetahuan dan derajat kesehatan.

Dengan demikian sekurangnya ada dua sektor yang perlu diperhatikan oleh pemerintah sehubungan dengan upaya memperluas kesempatan penduduknya untuk mencapai hidup layak yaitu pendidikan dan kesehatan. Dalam hal ini bisa terwujud melalui alokasi pengeluaran pemerintah di sektor pendidikan dan kesehatan. Dengan meningkatnya alokasi pengeluaran pemerintah di sektor publik tersebut maka akan meningkatkan pula produktivitas penduduk. Peningkatan produktivitas ini, pada gilirannya mampu meningkatkan pembangunan manusia yang selanjutnya dengan sendirinya berdampak pada penurunan angka kemiskinan. Beberapa hasil penelitian menunjukkan bahwa pengeluaran di sektor publik sangat berman- 
faat untuk meningkatkan pembangunan manusia dan mengurangi penduduk miskin, seperti penelitian yang telah dilakukan oleh antara lain Fan et. Al (2000), Gomanee at.al (2003), Brata (2005) dan Chemingui (2007).

Dalam kurun waktu 2007 dan 2008, berdasarkan hasil audit BPK atas Laporan Keuangan Provinsi Jawa Tengah, terlihat bahwa baik Pendapatan, Pengeluaran (Belanja), dan SILPA Provinsi Jawa Tengah, menunjukkan kecenderungan yang meningkat. Demikian pula dengan pengeluaran sektor publik bidang pendidikan dan kesehatan di Provinsi Jawa Tengah yang juga menunjukkan kecenderungan yang meningkat. Realisasi pengeluaran publik bidang pendidikan Provinsi Jawa Tengah pada tahun 2008 sebesar Rp127.932.205.596,00 atau meningkat sebesar Rp32.202.722.111,00 jika dibandingkan dengan tahun 2007. Namun, persentase pengeluaran bidang pendidikan terhadap jumlah belanja (Belanja Operasi, Belanja Modal, dan Belanja Tak Terduga) pada tahun 2008 yang sebesar 3,68 persen justru menunjukkan penurunan jika dibandingkan dengan tahun 2007 yang mencapai 3,77 persen. Demikian juga dengan realisasi pengeluaran bidang kesehatan yang meningkat pada tahun 2008 menjadi sebesar Rp429.715.515.972,00 jika dibandingkan dengan tahun 2007. Persentase pengeluaran bidang kesehatan terhadap jumlah belanja juga mengalami peningkatan, di mana pada tahun 2007 sebesar 4,42 persen dan pada tahun 2008 meningkat menjadi 12,35 persen.

Kenyataan terjadinya peningkatan pengeluaran pemerintah Provinsi Jawa Tengah, terutama pengeluaran bidang pendidikan dan kesehatan, menunjukkan adanya komitmen pemerintah Provinsi Jawa Tengah untuk meningkatkan pelayanan publik kepada masyarakat. Namun pengeluaran pemerintah tersebut belum tentu menyentuh langsung kepada masyarakat miskin. Jika hal tersebut terjadi dapat menyebabkan tidak tercapainya tujuan pemerintah dalam rangka menyejahterakan seluruh masyarakatnya. Kini saatnya untuk mengambil langkah-langkah peningkatan dengan menggunakan sumber-sumber keuangan daerah secara optimal untuk memperbaiki layanan pendidikan dan perluasan layanan kesehatan, dalam rangka meningkatkan kualitas sumber daya manusia yang semuanya digunakan untuk kesejahteraan masyarakat, sebagai salah satu cara menanggulangi kemiskinan yang masih menjadi masalah bagi pemerintah daerah.
Masalah yang dihadapi di Provinsi Jawa Tengah saat ini terkait dengan masalah rendahnya pembangunan manusia dan tingginya angka kemiskinan. Dua masalah tersebut, salah satu penyebabnya adalah rendahnya dukungan sumber pendanaan yang terbatas. Sumber dana yang terbatas tersebut menyebabkan relatif rendahnya pengeluaran pemerintah untuk membiayai sektor publik. Rendahnya tingkat investasi publik di Provinsi Jawa Tengah tercermin dari rendahnya alokasi pengeluaran pemerintah untuk sektor tersebut.

Di antara sektor publik yang krusial bagi pembangunan kualitas sumber daya manusia yang tercermin dari IPMadalah investasi pada sektor pendidikan dan kesehatan, yang pada akhirnya mempunyai pengaruh terhadap kemiskinan. Di Provinsi Jawa Tengah, realisasi bidang pendidikan terhadap total belanja pada tahun 2007 hanya mencapai 3,77 persen dan menurun pada tahun 2008 menjadi 3,68 persen. (Hasil Audit BPK, diolah).

Rendahnya alokasi pengeluaran di sektor pendidikan terjadi juga pada sektor kesehatan. Saat ini pengeluaran untuk sektor kesehatan terhadap PDRB masih rendah. Hal tersebut terlihat pula di Provinsi Jawa Tengah, di mana pada tahun 2007 persentase pengeluaran bidang kesehatan terhadap PDRB Provinsi Jawa Tengah hanya sebesar $0,07 \%$ dan pada tahun 2008 meningkat menjadi sebesar 0,26\% (BPS, 2009). Dengan demikian terlihat adanya kesenjangan antara keinginan untuk mengurangi kemiskinan melalui peningkatan pembangunan manusia, sementara dari sisi alokasi anggaran untuk sektor publik (pendidikan dan kesehatan) masih relatif rendah.

Pertanyaan yang hendak dijawab dalam studi ini adalah:

1. Bagaimana pola dan perkembangan pengeluaran pemerintah di sektor pendidikan dan kesehatan, indikator pembangunan manusia, dan indikator kemiskinan di Provinsi Jawa Tengah?

2. Bagaimana peran IPM dalam kaitannya dengan hubungan antara pengeluaran pemerintah di sektor pendidikan dan kesehatan dengan pengentasan kemiskinan di Provinsi Jawa Tengah?

Tujuan dalam penelitian ini yaitu:

1. Mendeskripsikan pola dan perkembangan pengeluaran pemerintah di sektor pendidikan dan kesehatan, indikator pembangunan manusia, dan indikator kemiskinan di Provinsi Jawa Tengah.

2. Menganalisis bagaimana peran IPM dalam kai- 
tannya dengan hubungan antara pengeluaran pemerintah di sektor pendidikan dan kesehatan dengan pengentasan kemiskinan di Provinsi Jawa Tengah, apakah sebagai variabel moderator atau sebagai variabel intervening.

\section{TINJAUAN PUSTAKA}

\section{Pengeluaran Pemerintah di Sektor Pendidikan dan Kesehatan}

Menurut Mahmudi (2007), pelayanan publik adalah segala kegiatan pelayanan yang diselenggarakan oleh penyelenggara pelayanan publik sebagai upaya pemenuhan kebutuhan publik dan pelaksanaan kententuan peraturan perundang-undangan. Dalam hal ini, yang dimaksud dengan penyelenggara pelayanan publik adalah instansi pemerintah, baik pemerintah pusat maupun pemerintah daerah. Sedangkan pelayanan publik yang harus diberikan kepada masyarakat diklasifikasikan dalam dua kategori utama yaitu:

\section{Pelayanan Kebutuhan Dasar}

Pelayanan kebutuhan dasar yang harus diberikan oleh pemerintah meliputi kesehatan, pendidikan dasar, dan bahan kebutuhan pokok masyarakat dengan uraian sebagai berikut:

\section{Kesehatan}

Kesehatan merupakan salah satu kebutuhan dasar masyarakat, oleh karena itu kesehatan adalah hak bagi setiap warga masyarakat yang dilindungi Undang-Undang Dasar. Perbaikan pelayanan kesehatan pada dasarnya merupakan suatu investasi sumber daya manusia untuk mencapai masyarakat yang sejahtera (welfare society). Tingkat kesehatan masyarakat akan sangat berpengaruh terhadap tingkat kesejahteraan masyarakat, karena tingkat kesehatan memiliki keterkaitan yang erat dengan kemiskinan. Sementara itu, tingkat kemiskinan akan terkait dengan tingkat kesejahteraan. Oleh karena kesehatan merupakan faktor utama kesejahteraan masyarakat yang hendak diwujudkan pemerintah, maka kesehatan harus menjadi perhatian utama pemerintah sebagai penyelenggara pelayanan publik. Pemerintah harus dapat menjamin hak masyarakat untuk sehat (right for health) dengan memberikan pelayanan kesehatan secara adil, merata, memadai, terjangkau, dan berkualitas.

\section{Pendidikan Dasar}

Sama halnya dengan kesehatan, pendidikan merupakan suatu bentuk investasi sumber daya manusia. Tingkat pendidikan juga berpengaruh terhadap tingkat kemiskinan karena pendidikan merupakan salah satu komponen utama dalam lingkaran setan kemiskinan. Salah satu cara untuk mengatasinya adalah melalui perbaikan kualitas pendidikan. Pelayanan pendidikan masyarakat yang paling elementer adalah pendidikan dasar, yang oleh pemerintah diterjemahkan dalam program Wajib Belajar Sembilan Tahun. Pemerintah hendak menjamin bahwa semua anak dapat bersekolah, sehingga diperlukan alokasi anggaran pendidikan yang besar. Dalam pemenuhan anggaran tersebut amanat amandemen UUD 1945 telah mensyaratkan alokasi anggaran pendidikan minimal sebesar 20 persen dari total anggaran.

\section{Bahan Kebutuhan Pokok Masyarakat}

Kebutuhan pokok masyarakat meliputi beras, minyak goreng, minyak tanah, gula pasir, telur, daging, dan sebagainya. Dalam hal penyediaan bahan kebutuhan pokok, pemerintah perlu menjamin stabilitas harga kebutuhan pokok masyarakat dan menjaga ketersediaannya di pasar maupun gudang dalam bentuk cadangan atau persediaan. Ketidakstabilan harga kebutuhan pokok yang tidak terkendali bisa menimbulkan inflasi yang tinggi (hiperinflasi) dan dapat menimbulkan ketidakstabilan politik. Selain menjaga stabilitas harga-harga umum, pemerintah juga perlu menjamin bahwa cadangan persediaan di gudang pemerintah cukup untuk memenuhi kebutuhan masyarakat sampai jangka waktu tertentu untuk menghindari terjadinya kepanikan masyarakat terhadap kelangkaan bahan kebutuhan pokok tersebut.

\section{Pelayanan Umum}

Selain pelayanan kebutuhan dasar, pemerintah sebagai instansi penyedia pelayanan publik juga harus memberikan pelayanan umum kepada masyarakat yang meliputi pelayanan administratif (yaitu pelayanan berupa penyediaan berbagai bentuk dokumen yang dibutuhkan publik), pelayanan barang (yaitu pelayanan yang menghasilkan berbagai bentuk/jenis barang yang menjadi kebutuhan publik), dan pelayanan jasa (yaitu pelayanan yang menghasilkan berbagai bentuk jasa yang dibutuhkan publik.

Terbatasnya akses-akses bagi kaum miskin menyebabkan mereka tak mampu untuk mengakumulasi kapital/modal yang diperlukan baginya untuk keluar dari jebakan kemiskinan (poverty trap). Akibat minimnya akumulasi kapital kaum miskin, konsekue- 
nsinya, kaum miskin tak mampu berperan aktif dalam kegiatan ekonomi dan merasakan berkah dari adanya pembangunan. Hal tersebutlah yang mendasari betapa pentingnya pembangunan manusia, di mana dalam pembangunan manusia tersebut tidak hanya meliputi dimensi kesejahteraan saja melainkan terkait juga dengan peningkatan kapasitas dasar manusia melalui akses terhadap pendidikan dan kesehatan terutama bagi masyarakat miskin.

Adalah merupakan kewajiban pemerintah untuk menyediakan barang publik. Teori public finance (Musgrave, 1989) mengungkapkan bahwa tidak seluruhnya semua masalah ekonomi diselesaikan oleh mekanisme pasar seperti halnya dengan social goods. Social goods yang dimaksud terkait dengan eksternalitas, distribusi pendapatan, masalah-masalah ekonomi lainnya (pengangguran, kemiskinan, inflasi, dan lain-lain). Dalam hal tersebut mekanisme pasar gagal menyelesaikannya (market failure). Pasar pada hakekatnya adalah wahana untuk mengekspresi-kan kebebasan individu, untuk mencari keuntungan individual. Oleh karena itu, aktivitas-aktivitas perekonomian yang bersifat kolektif publik dan atau aktivitas tidak bermotif keuntungan tidak bisa diselenggarakan oleh pasar. Karena adanya kegagalan pasar dan dalam kaitannya dengan ketiga peran pemerintah sebagai peran alokasi, peran distribusi, dan peran stabilitasi, maka kewajiban publik di bidang pendidikan dan kesehatan yang tidak disentuh oleh pasar, menjadi kewajiban pemerintah untuk menyediakannya.

\section{Pembangunan Manusia dan IPM}

Sejak tahun 1990, United Nations Development Programme (UNDP) telah menerbitkan laporan tahunan berupa Human Development Report (HDR). Dalam HDR tersebut dikeluarkan laporan tahunan mengenai indek pembangunan manusia/Human Development Index (HDI) di tiap negara. Indeks tersebut dikembangkan pada tahun 1990 oleh seorang peraih Hadiah Nobel berkebangsaan India yaitu Amartya Sen, dan seorang ekonom dari Pakistan, Mahbub Ul Haq, yang dibantu oleh Gustav Ranis dari Yale University dan Lord Meghnad Desai dari London School of Economic. Sen menyatakan bahwa HDI adalah sebuah pengukuran indeks manusia yang cukup kasar (vulgar measure) karena masih banyak keterbatasan. Namun, HDI menerapkan ukuran pada aspek-aspek pengembangan kualitas manusia secara lebih kom- prehensif daripada hanya sekedar pendapatan per kapita seperti yang dilakukan selama ini dalam menentukan atau menunjukkan apakah suatu negara itu negara maju, berkembang, atau belum berkembang. HDI juga merupakan salah satu bahan kajian atau topik pembahasan bagi para peneliti untuk meneliti ukuran-ukuran kualitas manusia di sebuah negara secara luas dan beragam.

Dalam Human Development Report (UNESCO, 2007) dijelaskan bahwa Human Development Index (HDI) merupakan suatu konstruksi pengukuran atas dasar konsep right based approach to human development. HDI melakukan pengukuran rata-rata capaian setiap individu negara yang menyangkut tiga dimensi dasar dari proses pengembangan kualitas manusia. Pengukuran ini dilakukan dengan menetapkan beberapa asumsi dasar bahwa manusia yang berkualitas adalah:

Manusia yang dapat hidup sehat dan panjang umur, sebagaimana diukur dengan Angka Harapan Hidup sejak waktu lahir (life expectancy at birth);

Manusia yang memiliki kecakapan dan pendidikan yang diperlukan bagi hidupnya, sebagaimana diukur melalui indikator angka literasi orang dewasa (adult literacy rate) dengan bobot penilaian dua pertiga, serta indikator kombinasi Angka Partisipasi Kasar (APK) pendidikan dasar, menengah dan tinggi dengan bobot penilaian satu pertiga dari penghitungan indeks pendidikan;

Manusia yang dapat mencapai standar hidup layak, sebagaimana diukur dengan logaritma pendapatan domestik bruto (PDB) per kapita yang menggunakan indikator purchasing power parity (PPP) yang dihitung dalam dolar Amerika.

Pembangunan manusia yang dimaksudkan dalam IPM tidak sama dengan pengembangan sumber daya manusia yang biasanya dimaksudkan dalam teori ekonomi. Sumber daya manusia menunjuk pada manusia sebagai salah satu faktor produksi, yaitu sebagai tenaga kerja yang produktivitasnya harus ditingkatkan. Dalam hal ini manusia hanya sebagai alat (in$p u t)$ untuk mencapai tujuan yaitu peningkatan output barang dan jasa.

Sedangkan manusia di dalam IPM lebih diartikan sebagai tujuan pembangunan yang orientasi akhirnya pada peningkatan kesejahteraan.

\section{Kemiskinan}


Kemiskinan menurut Mudrajad Kuncoro (2000) adalah ketidakmampuan untuk memenuhi standar hidup minimum. Permasalahan standar hidup yang rendah berkaitan pula dengan jumlah pendapatan yang sedikit (kemiskinan), perumahan yang kurang layak, kesehatan dan pelayanan kesehatan yang buruk, tingkat pendidikan masyarakat yang rendah sehingga berakibat pada rendahnya sumber daya manusia dan banyaknya pengangguran. Tingkat standar hidup dalam suatu negara bisa diukur dari beberapa indikator antara lain Gross National Product (GNP) per capita, pertumbuhan relatif nasional dan pendapatan per kapita, distribusi pendapatan nasional, tingkat kemiskinan, dan tingkat kesejahteraan masyarakat.

Menurut Todaro (2000), besarnya kemiskinan dapat diukur dengan atau tanpa mengacu kepada garis kemiskinan (poverty line). Konsep yang mengacu kepada garis kemiskinan disebut kemiskinan absolut, sedangkan konsep yang pengukurannya tidak didasarkan pada garis kemiskinan disebut kemiskinan relatif. Kemiskinan absolut adalah derajat kemiskinan di bawah, di mana kebutuhan-kebutuhan minimum untuk bertahan hidup tidak dapat terpenuhi. Ini adalah suatu ukuran tetap (tidak berubah) di dalam bentuk suatu kebutuhan kalori minimum di tambah komponen-komponen non makanan yang juga sangat diperlukan untuk survive. Sedangkan kemiskinan relatif adalah suatu ukuran mengenai kesenjangan di dalam distribusi pendapatan, biasanya dapat didefinisikan di dalam kaitannya dengan tingkat rata-rata dari distribusi yang dimaksud.

Mengutip pendapat Nurske, Jhingan (2000) dan Mudrajad Kuncoro (2003) menyatakan bahwa negara/ daerah yang tingkat kemiskinannya tinggi, umumnya terjerat ke dalam apa yang disebut lingkaran kemiskinan (vicious circle). Nurske menjelaskan bahwa lingkaran kemiskinan mengandung arti deretan melingkar kekuatan-kekuatan yang satu sama lain berinteraksi sedemikian rupa sehingga menempatkan suatu negara/daerah yang tingkat kemiskinannya tinggi tetap berada dalam keadaan terbelakang. Menurut Nurske, kemiskinan adalah sebab sekaligus akibat.

\section{Teori Pertumbuhan Ekonomi}

Pertumbuhan ekonomi merupakan suatu proses kenaikan output total secara terus menerus dalam jangka panjang. Pengertian pertumbuhan ekonomi yang dimaksud adalah tanpa memandang kenaikan itu lebih besar ataukah lebih kecil daripada tingkat pertumbuhan penduduk, atau apakah perubahan dalam struktur ekonomi berlaku atau tidak (Sadono Sukirno, 1981). Teori pertumbuhan ekonomi menjelaskan mengenai faktor-faktor yang menentukan pertumbuhan ekonomi dan prosesnya dalam jangka panjang, penjelasan mengenai bagaimana faktor-faktor itu berinteraksi satu dengan yang lainnya, sehingga menimbulkan terjadinya proses pertumbuhan (Lincolin Arsyad, 1999).

Istilah pertumbuhan ekonomi sering didefinisikan oleh para ahli dengan istilah pembangunan ekonomi. Pembangunan ekonomi adalah usaha-usaha untuk meningkatkan taraf hidup suatu bangsa yang sering diukur dengan tinggi rendahnya pendapatan perkapita, tetapi biasanya istilah pertumbuhan ekonomi digunakan untuk menyatakan perkembangan ekonomi di negara-negara maju dan istilah pembangunan ekonomi untuk menyatakan perkembangan ekonomi di negara-negara berkembang. Perekonomian dapat dinyatakan dalam keadaan berkembang jika pendapatan perkapita menunjukkan kecenderungan meningkat dalam jangka panjang. Tetapi tidak berarti kenaikannya secara terus menerus. Suatu perekonomian akan dapat mengalami penurunan dalam tingkat kegiatan ekonominya apabila terjadi resesi ekonomi, kekacauan politik dan penurunan ekspor. Tetapi jika keadaan demikian hanya bersifat sementara, kegiatan ekonomi meningkat secara rata-rata dari tahun ke tahun, maka masyarakat tersebut dapatlah dikatakan mengalami pembangunan ekonomi.

\section{Hubungan antara Pengeluaran Publik, Pembangunan Manusia, dan Kemiskinan}

Masalah kemiskinan yang identik dengan jumlah pendapatan masyarakat yang tidak memadai, harus selalu menjadi prioritas dalam pembangunan suatu negara. Meskipun masalah kemiskinan akan selalu muncul karena sifat dasar dari kemiskinan adalah relatif, namun ketika dari sebuah negara mengalami peningkatan taraf hidup, maka standar hidup akan berubah. Agenda mengatasi kemiskinan bagi suatu negara berkaitan dengan banyaknya faktor yang berhubungan dengan apa yang diakibatkan oleh kemiskinan itu sendiri, karena dampak dari kemiskinan itu akan berhubungan dengan kondisi fundamental yang menjadi syarat berlangsungnya pembangunan suatu negara yang berkelanjutan. 
Menurut Novianto Dwi Wibowo (2003), esensi utama dari masalah kemiskinan adalah masalah aksesibilitas. Aksesibilitas dalam hal ini berarti kemampuan seseorang atau sekelompok orang dalam masyarakat untuk dapat mencapai atau mendapatkan sesuatu yang sebenarnya merupakan kebutuhan dasarnya dan seharusnya menjadi haknya sebagai manusia dan sebagai warga negara.

Seseorang atau sekelompok orang yang miskin, akan mempunyai aksesibilitas yang rendah dan terbatas terhadap berbagai kebutuhan dan layanan dibandingkan mereka yang termasuk golongan menengah maupun golongan kaya. Akses-akses yang tidak bisa didapat oleh masyarakat miskin yaitu:

- Akses untuk mendapatkan makanan yang layak

- Akses untuk mendapatkan sandang yang layak

- Akses untuk mendapatkan rumah yang layak

- Akses untuk mendapatkan layanan kesehatan baik dan layak

- Akses untuk mendapatkan layanan pendidikan

- Akses kepada leisure dan entertainment

- Akses untuk mendapatkan kualitas hidup yang baik dengan terpenuhinya semua basic need dan supporting needs.

Permasalahan aksesibilitas ini menjadi penting karena kemiskinan akan menjadi lingkaran setan karenanya, di mana golongan miskin tidak akan terangkat atau terlepas dari kemiskinan ketika mereka tidak dapat meningkatkan intelektualitas dan sumber daya mereka. Namun karena adanya masalah aksesibilitas tersebut, peningkatan ini akan menjadi suatu yang tidak mungkin dilakukan. Pada akhirnya, sebagai akumulasi dari beban fisik dan psikologis akan menimbulkan berbagai ekses negatif seperti keresahan sosial.

Menurut Mahmudi (2007), dalam suatu lingkaran setan kemiskinan terdapat tiga poros utama yang menyebabkan seseorang menjadi miskin yaitu 1) rendahnya tingkat kesehatan, 2) rendahnya pendapatan, dan 3) rendahnya tingkat pendidikan. Rendahnya tingkat kesehatan merupakan salah satu pemicu terjadinya kemiskinan karena tingkat kesehatan masyarakat yang rendah akan menyebabkan tingkat produktivitas menjadi rendah. Tingkat produktivitas yang rendah lebih lanjut menyebabkan pendapatan rendah, dan pendapatan yang rendah menyebabkan terjadinya kemiskinan. Kemiskinan itu selanjutnya menyebabkan seseorang tidak dapat menjangkau pendidikan yang berkualitas serta membayar biaya pemeliharaan dan perawatan kesehatan.
Berdasarkan hal tersebut maka salah satu hal yang bisa dilakukan pemerintah dalam mengatasi permasalahan kemiskinan adalah upaya untuk meningkatkan kualitas sumber daya manusia melalui peningkatan kualitas pembangunan manusia. Dalam hal ini, pembangunan manusia di-proxy dengan IPM atau $\mathrm{Hu}$ man Development Index (HDI) yang merupakan suatu indeks komposit untuk mengukur pencapaian kualitas pembangunan manusia untuk dapat hidup secara lebih berkualitas, baik dari aspek kesehatan, pendidikan, maupun aspek ekonomi. Di mana IPM merupakan indeks pengembangan manusia yang dilihat dari sisi perluasan, pemerataan, dan keadilan baik dalam bidang kesehatan, pendidikan, maupun kesejahteraan masyarakat.

Peranan pemerintah disini adalah sebagai penyedia kewajiban publik di bidang pendidikan dan kesehatan yang tidak disentuh oleh pasar karena adanya kegagalan pasar dan dalam kaitannya dengan peranan pemerintah sebagai peranan alokasi, peranan distribusi, dan peranan stabilisasi. Menurut Center for the Study of Living Standars (2001) dalam Toyamah, dkk (2004) menyatakan bahwa pendidikan adalah elemen penting untuk memerangi kemiskinan, memberdayakan perempuan, serta menyelamatkan anak-anak dari upaya eksploitasi. Demikian juga pernyataan dari UNICEF yang mengatakan bahwa pendidikan adalah investasi yang penting untuk memperoleh pekerjaan yang layak dengan upah yang tinggi.

Investasi publik di bidang pendidikan dan kesehatan akan memberikan kesempatan pendidikan dan pelayanan kesehatan yang lebih merata kepada masyarakat sehingga sumber daya manusia (SDM) handal yang sehat menjadi semakin bertambah. Meningkatnya kesehatan dan pendidikan akan mendorong peningkatan kualitas sumber daya manusia dan peningkatan produktivitas tenaga kerja, yang pada gilirannya akan meningkatkan pendapatan masyarakat. Dengan demikian diharapkan kondisi ini akan memajukan perekonomian masyarakat dengan bertambahnya kesempatan kerja serta berkurangnya kemiskinan.

Telah banyak penelitian yang dilakukan yang terkait dengan pentingnya pembangunan manusia sebagai salah satu cara untuk meningkatkan kesejahteraan masyarakat melalui pengalokasian dana pemerintah dalam upaya pengentasan kemiskinan. Studi - studi tersebut dilakukan oleh Fan, et. Al (2000), Michael Boozer, Gustav Ranis, Frances Stewart, Tavneet Suri (2003), Brata (2005), Chemingui (2007), Agussalim (2007), Yani Mulyaningsih (2008), Fhina Andrea Christy, Priyo 
Hari Adi (2009), dan Suhyun Jung, Seong-Hoon Cho, Roland K Roberts (2009), Brata (2005) dan Yani Mulyaningsih (2008). Studi - studi mereka memberikan inspirasi yang signifikan bagi studi ini. Utamanya, studi yang dilakukan oleh Brata (2005) dan Yani Mulyaningsih (2008). Brata (2005) dan Yani Mulyaningsih (2008) menyebutkan bahwa pembangunan manusia yang diproxi dari IPM(Human Development Index) memuat tiga dimensi penting dalam pembangunan, yaitu dimensi yang terkait dengan (a) aspek pemenuhan kebutuhan akan hidup panjang umur (longevity) dan hidup sehat (healthy life), (b) upaya untuk mendapatkan pengetahuan (the knowlodge) dan (c) akses sumber daya yang mampu memenuhi standar hidup. Ke tiga dimensi ini secara langsung maupun tidak langsung terkait dengan tingkat kemiskinan.

Hal yang menarik dari studi ini untuk dikedepankan dan yang membedakan dengan studi - studi sebelumnya adalah dilakukannya analisis yang mengkaji bagaimana peran IPM dalam kaitannya dengan hubungan antara pengeluaran pemerintah di sektor pendidikan dan kesehatan dengan tingkat kemiskinan. Pertanyaan sentral dari studi ini adalah apakah IPM merupakan variabel moderator (variabel yang memperkuat atau memperlemah) atau variabel intervening (variabel yang memediasi) hubungan antara pengeluaran pemerintah tersebut dengan tingkat kemiskinan.

\section{Kerangka Pemikiran Teoritis}

Permasalahan besar yang dihadapi di seluruh kabupaten/kota di Provinsi Jawa Tengah saat ini terkait dengan masalah rendahnya pembangunan manusia dan tingginya angka kemiskinan. Salah satu hal yang biasa dilakukan pemerintah saat ini dengan melakukan investasi pada sektor publik. Investasi sektor publik tersebut bisa di-proxy dari pengeluaran pemerintah. Di antara sektor publik yang bermanfaat bagi peningkatan pembangunan manusia dan pengurangan kemiskinan adalah sektor pendidikan dan kesehatan.

Pendidikan merupakan elemen terpenting dalam memberantas kemiskinan. Seseorang yang memperoleh pendidikan akan memperoleh kesempatan yang lebih baik dan bisa memperbaiki standar hidupnya. Pengaruh pendidikan tidak hanya mempengaruhi kemampuan individu untuk mendapatkan tingkat upah maupun pendapatan yang tinggi, tetapi juga terhadap perilaku dan pengambilan keputusan, yang akan meningkatkan kemungkinan sukses dalam menjang- kau kebutuhan pokok, bahkan pendidikan akan membuat seseorang terhindar dari kondisi miskin (Zuluaga, 1990). Rendahnya tingkat pendapatan juga berdampak pada rendahnya kemampuan seseorang mengakses pelayanan kesehatan. Apabila kualitas SDM rendah yang tercermin dari tingkat pendidikan dan kesehatan yang rendah maka akan tercermin pula pada rendahnya IPM. IPM adalah indeks komposit dari harapan hidup, melek huruf dewasa, rata-rata lama sekolah, dan pengeluaran per kapita.

Dari pembahasan di atas terungkap bahwa dengan semakin besarnya alokasi anggaran di sektor pendidikan dan kesehatan menyebabkan semakin banyaknya masyarakat yang mendapat akses atas pendidikan dan kesehatan. Seperti yang disebutkan oleh Amartya Sen (1985), bahwa masalah kemiskinan tidak hanya masalah income semata melainkan terkait dengan kapabilitas-kapabilitas yang harus dimiliki oleh seseorang dalam hal ini salah satunya menyangkut masalah akses-akses, baik terhadap pendidikan, kesehatan dan kesempatan kerja. Dengan demikian penanganan kemiskinan akan lebih komprehensif.

Berdasarkan uraian tersebut di atas maka alur pikir penelitian tentang peran pembangunan manusia (dalam hal ini di-proxy dengan indeks pembangunan manusia) dalam kaitannya dengan hubungan antara pengeluaran pemerintah sektor publik terhadap pengurangan kemiskinan, baik IPMsebagai variabel moderating maupun sebagai variabel intervening adalah sebagai berikut:

\section{Gambar 1. Skema Kerangka Pemikiran Teoritis}

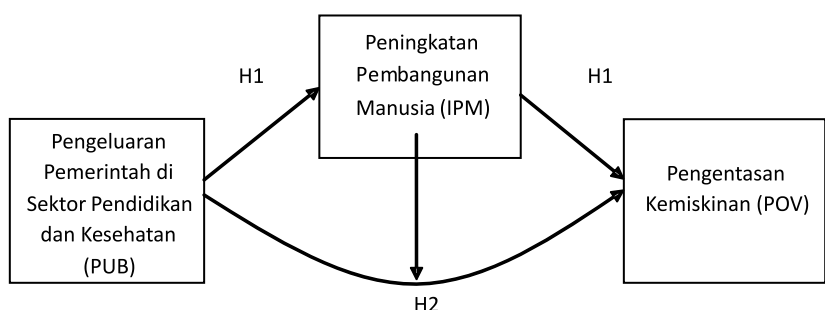

\section{Hipotesis}

Berdasarkan latar belakang, perumusan masalah, serta uraian pada peneliti terdahulu serta kerangka pemikiran teoritis, maka dalam penelitian ini dapat diajukan beberapa hipotesis sebagai berikut: 
H1 : Pengeluaran pemerintah di sektor pendidikan dan kesehatan berpengaruh positif terhadap IPM, selanjutnya IPM berpengaruh negatif terhadap tingkat kemiskinan (IPM berfungsi sebagai variabel intervening (variabel yang memediasi) hubungan antara pengeluaran pemerintah pemerintah tersebut dengan tingkat kemiskinan).

H2 : IPM mempengaruhi pengentasan kemiskinan secara negatif dan signifikan; dan IPM memperkuat atau memperlemah hubungan antara pengeluaran pemerintah tersebut dengan tingkat kemiskinan (IPM berfungsi sebagai variabel moderating)

\section{METODE PENELITIAN}

\section{Operasional Variabel dan Data}

Variabel yang digunakan dalam penelitian ini terdiri dari (a) pengeluaran pemerintah di sektor pendidikan dan kesehatan yang diukur dari realisasi APBD 35 Kabupaten/Kota di sektor pendidikan dan kesehatan di Jawa Tengah (PUB), dalam satuan juta rupiah. (b) Pembangunan manusia yang di-proxy dari angka IPM(IPM) 35 Kabupaten/Kota di Jawa Tengah yang diukur dalam satuan angka. (c) Angka kemiskinan yang diukur dari persentase penduduk miskin regional (POV) 35 Kabupaten/Kota di Jawa Tengah. Adapun periode kajian studi ini adalah tahun 2007 -2008 .

Data PUB, IPM dan POV di atas diperoleh dari Provinsi Jawa Tengah Dalam Angka, Kabupaten/Kota Dalam Angka, Statistik Keuangan Pemerintah Daerah Jawa Tengah, Indikator Utama Sosial Politik dan Keamanan Provinsi Jawa Tengah, Perda Pertanggungjawaban APBD pada Biro Keuangan Provinsi Jawa Tengah, Publikasi BPS dan literaturliteratur yang relevan dengan studi ini. Selain itu, data juga diperoleh dengan mengunduh dari situs - situs antara lain: www.bps.go.id, www.bi.go.id, www.jateng.bappeda.go.id.

\section{Teknik Analisis}

Berdasarkan tujuan studi dan pengujian hipotesis yang telah dikemukakan terdahulu, studi ini menggunakan teknik analisis statistik deskriptif dan teknik analisis kuantitatif.

\section{Analisis Statistik Deskriptif}

Statistik deskriptif menurut Imam Ghozali (2009), memberikan gambaran atau deskripsi suatu data yang dilihat dari nilai rata-rata (mean), standar deviasi, varian, maksimum, minimum, sum, range, kurtosis, dan kemencengan distribusi (skewness). Data yang digunakan pada penelitian ini adalah data runtun waktu yang merupakan data tahunan kabupaten/kota di Provinsi Jawa Tengah, dari tahun 2007 hingga tahun 2008, tentang pencapaian kinerja indikator kabupaten/kota di Provinsi Jawa Tengah yang berkaitan dengan keuangan daerah, pembangunan manusia, dan kemiskinan yang dibandingkan dengan capaian secara regional dan nasional. Metode yang didasarkan pada analisis ini adalah dengan pendeskripsian faktor-faktor yang berhubungan dengan permasalahan yang dimaksud sebagai pendukung hasil dari analisis metode kuantitatif.

\section{Analisis Kuantitatif}

Studi ini menggunakan Analisis Regresi Berganda (Multiple Regression Analysis) untuk menganalisis data. Analisis regresi berganda ini adalah analisis mengenai ketergantungan suatu variabel dependent (tak bebas) terhadap satu atau lebih variabel independent (bebas) untuk mengestimasi nilai rata-rata variabel dependen berdasarkan nilai tepat variabel independen (Gujarati, 2003). Pusat perhatian pada upaya menjelaskan dan mengevaluasi hubungan antara satu variabel dengan satu atau lebih variabel independen. Hasil analisis regresi adalah berupa koefisien regresi untuk masing-masing variabel independen. Koefisien ini diperoleh dengan cara memprediksi nilai variabel dependen dengan suatu persamaan. Dalam analisis regresi, selain mengukur kekuatan antara dua variabel atau lebih, juga menunjukkan arah hubungan antara variabel dependen dengan variabel independen.

Analisis Regresi Berganda dengan variabel moderating dan intervening digunakan untuk menjawab bagaimana peran IPM dalam kaitannya antara hubungan pengeluaran pemerintah di sektor pendidikan dan kesehatan dengan pengentasan kemiskinan. Menurut Imam Ghozali (2009), variabel moderating adalah variabel independen yang akan memperkuat atau memperlemah hubungan antara variabel independen lainnya terhadap variabel dependen. Tidak seperti variabel moderating, variabel intervening merupakan variabel antara atau mediating yang fungsinya memediasi hubungan antara variabel independen dengan 
variabel dependen.

\section{Analisis Regresi Berganda dengan Variabel Moderating}

Ada tiga cara yang ditawarkan untuk menguji variabel moderating (Imam Ghozali, 2009), yaitu:

\section{Uji Interaksi}

Uji interaksi atau sering disebut dengan Moderated Regression Analysis (MRA) merupakan aplikasi khusus regresi berganda linier di mana dalam persamaan regresinya mengandung unsur interaksi (perkalian dua atau lebih variabel independen). Menurut Imam Ghozali (2009), moderated regression analysis (MRA) menggunakan pendekatan analitik yang mempertahankan integritas sampel dan memberikan dasar untuk mengontrol pengaruh variabel moderator. Dengan menggunakan model MRA dengan satu variabel independen (yaitu variabel Pengeluaran Publik), maka dibandingkan tiga persamaan regresi untuk menentukan jenis variabel moderator yaitu sebagai berikut:

$$
\begin{aligned}
P O V= & \beta_{0}+\beta_{1} P U B+\varepsilon \ldots \ldots \ldots \ldots \ldots \ldots \ldots \ldots \ldots \ldots \\
P O V= & \beta_{0}+\beta_{1} P U B+\beta_{2} I P M+\varepsilon \ldots \ldots \ldots \ldots \ldots \ldots \\
P O V= & \beta_{0}+\beta_{1} P U B+\beta_{2} I P M+\beta_{3}(P U B * \\
& I P M)+\varepsilon
\end{aligned}
$$

di mana: $\beta_{1}, \beta_{2}$, dan $\beta_{3}<0$

$P O V=$ Persentase penduduk miskin $(\%)$

$P U B=$ Realisasi pengeluaran pemerintah di sektor Pendidikan dan Kesehatan (juta $\mathrm{Rp})$

$I P M=$ Indeks Pembangunan Manusia

Menurut Imam Ghozali (2009), jika persamaan (2) dan (3) tidak berbeda secara signifikan atau $\left(\beta_{3}\right.$ $=0 ; \beta_{2} \neq 0$ ) maka IPM bukanlah variabel moderator, tetapi sebagai variabel independen. Variabel IPM merupakan variabel pure moderator jika persamaan (1) dan (2) tidak berbeda, tetapi harus berbeda dengan persamaan ( 3$)$ atau $\left(\beta_{2}=0 ; \beta_{3} \neq 0\right)$. Selain itu, variabel IPM merupakan variabel quasi moderator jika persamaan (1), (2), dan (3) harus berbeda dengan lainnya atau $\left(\beta_{2} \neq \beta_{3} \neq 0\right)$.

\section{Uji Nilai Selisih Mutlak}

Frucot dan Shearon (1991) dalam Imam Ghozali (2009) mengajukan model regresi yang agak berbeda untuk menguji pengaruh moderasi yaitu dengan model nilai selisih mutlak dari variabel independen dengan rumus dasar persamaan regresi sebagai berikut:

$P O V=\beta_{0}+\beta_{1} P U B+\beta_{2} I P M+\beta_{3}|P U B * I P M|+\varepsilon$

di mana: $\beta_{1}, \beta_{2}$, dan $\beta_{3}<0$

$P O V=$ Persentase penduduk miskin (\%)

$P U B=$ Realisasi Pengeluaran Bidang

$\begin{array}{ll}I P M & =\text { Pendidikan dan Kesehatan (juta Rp) } \\ \text { IPM }\end{array}$

\section{Uji Residual}

Pengujian variabel moderating dengan uji interaksi maupun uji selisih nilai absolut mempunyai kecenderungan akan terjadi multikolonieritas yang tinggi antar variabel independen, sehingga hal ini akan menyalahi asumsi klasik dalam regresi ordinary least square (OLS). Untuk mengatasi multikolonieritas ini, maka dikembangkan metode lain yang disebut uji residual (Imam Ghozali, 2009). Langkah uji residual pada hipotesis ketiga pada penelitian ini, dapat digambarkan dengan persamaan regresi sebagai berikut:

\section{Gambar 2. Analisis Regresi Berganda dengan Variabel Moderating}

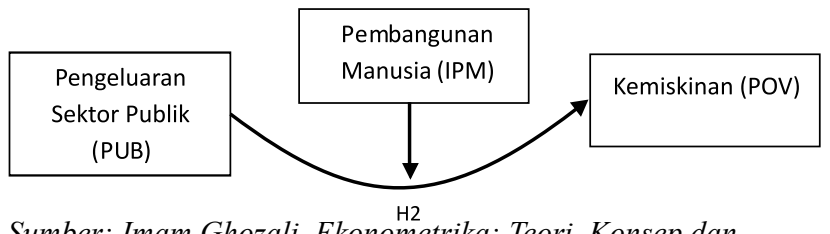

Sumber: Imam Ghozali. Ekonometrika; Teori, Konsep dan Aplikasi dengan SPSS 17

Dari gambar tersebut dibuat persamaan regresi sebagai berikut:

$I P M=\beta_{0}+\beta_{1} P U B+\varepsilon$

$|\varepsilon|=\beta_{0}-\beta_{1} P O V$

Persamaan regresi (6) menggambarkan apakah variabel IPM merupakan variabel moderating dan hal ini ditunjukkan dengan nilai koefisien $\beta_{1} P O V$ signifikan dan negatif hasilnya (yang berarti adanya lack of fit antara PUB dan IPM sehingga mengakibatkan POV meningkat atau berpengaruh negatif).

\section{Analisis Regresi dengan Variabel Intervening}

Variabel intervening merupakan variabel antara yang berfungsi memediasi hubungan antara variabel independen dengan variabel dependen. Menurut Baron dan Kenny (1986) dalam Imam Ghozali (2009), suatu variabel disebut mediator atau intervening jika variabel tersebut ikut mempengaruhi hubungan antara 
variabel independen dan variabel dependen.

\section{Analisis Jalur (Path Analysis)}

Menurut Imam Ghozali (2009), untuk menguji pengaruh variabel intervening digunakan metode analisi jalur (path analysis). Analisis jalur merupakan penggunaan analisis regresi untuk menaksir hubungan kausalitas antar variabel (model casual) yang telah ditetapkan sebelumnya berdasarkan teori. Analisis jalur tidak dapat menentukan hubungan sebab akibat dan juga tidak dapat digunakan sebagai substitusi untuk melihat hubungan kausalitas antar variabel. Analisis jalur digunakan untuk menentukan pola hubungan antara tiga atau lebih variabel dan tidak dapat digunakan untuk mengkonfrimasi atau menolak hipotesis kasualitas imajiner.

Dalam penelitian ini, hubungan antara pengeluaran sektor publik dengan kemiskinan di mediasi oleh pembangunan manusia, dengan model analisis jalur sebagai berikut:

\section{Gambar 3. Model Analisis Jalur (Path Analysis)}

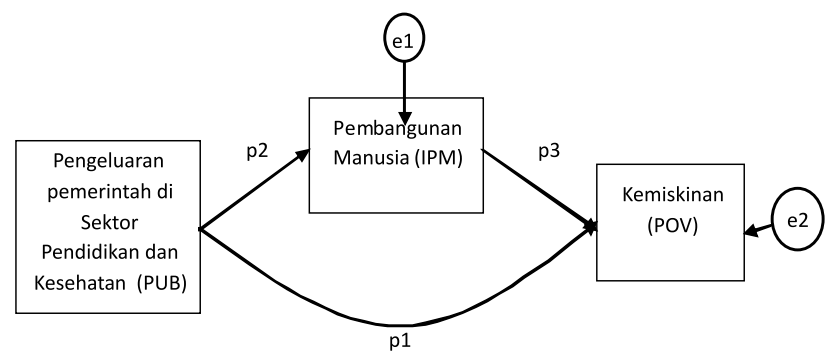

Sumber: Imam Ghozali. Ekonometrika: Teori, Konsep, dan Aplikasi dengan SPSS 17

Diagram jalur memberikan gambaran secara eksplisit hubungan kausalitas antar variabel berdasarkan teori. Anak panah menunjukkan hubungan antar variabel. Model bergerak dari kiri ke kanan dengan implikasi prioritas hubungan kasualitas variabel yang dekat ke sebelah kiri. Setiap nilai $\mathrm{p}$ menggambarkan jalur dan koefisian jalur. Berdasarkan model jalur pada Gambar 3 diajukan hubungan berdasarkan teori bahwa pengeluaran sektor publik mempunyai hubungan langsung dengan kemiskinan (p1). Namun demikian, pengeluaran sektor publik di bidang pendidikan dan kesehatan juga mempunyai hubungan tidak langsung dengan kemiskinan yaitu dari pengeluaran sektor publik ke pembangunan manusia (p2) baru kemudian ke kemiskinan (p3). Total pengaruh hubungan dari pengeluaran sektor publik ke kemiskinan (korelasi pengeluaran sektor publik dan kemiskinan) sama dengan pengaruh langsung pengeluaran sektor publik ke kemiskinan (koefisien path atau regresi p1) ditambah pengaruh tidak langsung yaitu koefisien path dari pengeluaran sektor publik ke pembangunan manusia yaitu p2 dikalikan dengan koefisien path dari pembangunan manusia ke kemiskinan yaitu p3, sebagaimana berikut ini:

Pengaruh langsung

pengeluaran sektor publik ke

kemiskinan $\quad=\mathrm{p} 1$

Pengaruh tidak langsung

pengeluaran sektor publik

ke pembangunan manusia

kemudian ke kemiskinan

Total pengaruh (korelasi

pengeluaran sektor publik ke

kemiskinan)

$$
\begin{aligned}
& =\mathrm{p} 2 \times \mathrm{p} 3 \\
& =\mathrm{p} 1+(\mathrm{p} 2 \times \mathrm{p} 3)
\end{aligned}
$$

Selanjutnya, pengaruh mediasi yang ditunjukkan dengan perkalian koefisien (p2 x p3) adalah signifikan atau tidak, akan diuji dengan uji Sobel untuk menghitung nilai standar error dari koefisien pengaruh tidak langsung tersebut, dengan rumus sebagai berikut:

$S p 2 p 3=\sqrt{p 3^{2} S p 2^{2}+p 2^{2} S p 3^{2}+S p 2^{2} S p 3^{2}}$.

Berdasarkan hasil perhitungan $\mathrm{Sp} 2 \mathrm{p} 3$ tersebut di atas, dihitung nilai $t$ statistik untuk pengaruh mediasi dengan rumus sebagai berikut:

$t$ hitung $=\frac{p 2 p 3}{S p 2 p 3}$

Jika hasil hasil thitung lebih besar dari t tabel, maka dapat disimpulkan bahwa nilai koefisien mediasi pengaruh tidak langsung (p2 x p3) adalah signifikan yang menunjukkan adanya pengaruh mediasi. Di mana, nilai $t$ tabel pada tingkat signifikansi $\alpha=0,05$ sebesar 1,96.

Masih menurut Imam Ghozali (2009), koefisien jalur adalah standardized koefisien regresi. Koefisien jalur dihitung dengan membuat dua persamaan struktural yaitu persamaan regresi yang menunjukkan hubungan yang dihipotesiskan. Dalam penelitian ini ada dua persamaan, yaitu:

$I P M=\beta_{0}+\beta_{1} P U B+\varepsilon$

$P O V=\beta_{0}+\beta_{1} P U B+\beta_{2} I P M+\varepsilon$

Nilai standardized koefisien untuk variabel pengeluaran sektor publik (PUB) pada persamaan (9) akan memberikan nilai $\mathrm{p} 2$. Sedangkan pada persamaan (10), nilai standardized koefisien untuk variabel pengeluaran sektor publik (PUB) akan memberikan 
nilai $\mathrm{p} 1$ dan nilai standardized koefisien untuk variabel pembangunan manusia (IPM) akan memberikan nilai p3.

\section{Pendeteksian Penyimpangan Asumsi Klasik}

Teorema Gauss-Markov adalah teorema yang melekat dalam metode kuadrat terkecil (OLS). Teorema ini menyatakan bahwa apabila semua asumsi linier klasik dipenuhi, maka akan diketemukan model penaksir yang tidak bias, linier dan merupakan penaksir terbaik (best linier unbiased estimator $=$ BLUE) (Gujarati, 2003 dalam Insukindro, 2004). Oleh karena itu, penaksir OLS ( $b_{0}$ dan $b_{1}$ ) yang bersifat BLUE mengandung arti sebagai berikut:

- Linier, di mana $b_{0}$ dan $b_{1}$ merupakan suatu fungsi linier dari variabel acak Y di dalam suatu model regresi.

- Unbiased, di mana $b_{0}$ dan $b_{1}$ tidak bias, terutama dalam regresi dengan menggunakan sampel besar sehingga penaksir parameter diperoleh dari sampel besar kira-kira lebih mendekati nilai parameter yang sebenarnya.

- Efficient estimator, di mana $b_{0}$ dan $b_{1}$ mempunyai varian yang minimum atau penaksir yang efisien.

Secara teoritis model OLS akan menghasilkan estimasi nilai parameter model penduga yang sahih bila dipenuhi asumsi Tidak Ada Autokorelasi, Tidak Ada Multikolinearitas, dan Tidak Ada Heteroskedastisitas. Apabila seluruh asumsi klasik tersebut telah terpenuhi maka akan menghasilkan hasil regresi yang best, linear, unbias, efficient of estimation (BLUE). Untuk memenuhi asumsi-asumsi di atas, maka estimasi regresi hendaknya dilengkapi dengan uji-uji yang diperlukan, seperti uji heteroskedastisitas, uji autokorelasi, uji multikolinearitas, dan uji normalitas.

\section{HASIL DAN PEMBAHASAN}

\section{Hasil Analisis Statistik Deskriptif}

Secara garis besar, alokasi pengeluaran pemerintah di sektor pendidikan dan kesehatan di kabupaten/kota di Provinsi Jawa Tengah menunjukkan kecenderungan yang meningkat. Demikian pula dengan indikator yang berkaitan dengan pembangunan manusia, seperti angka harapan hidup, angka melek huruf, rata-rata lama sekolah, dan pengeluaran per kapita per bulan; menunjukkan kecenderungan yang meningkat pula. Peningkatan pengeluaran pemerintah di sektor pendidikan dan kesehatan maupun indikator pembangunan manusia, dibarengi dengan semakin membaiknya indikator kemiskinan yang ditandai dengan semakin menurunnya indikator jumlah dan persentase penduduk miskin.

Menurut BPS, jumlah pengeluaran sektor publik untuk bidang pendidikan dan kesehatan menunjukkan kecenderungan yang meningkat. Pada tahun 2008, pengeluaran sektor publik yang tertinggi adalah Kabupaten Purworejo sebesar Rp799.174,67 juta berupa pengeluaran bidang pendidikan sebesar Rp653.523,92 juta atau 22,03 persen dari total pengeluaran, dan pengeluaran bidang kesehatan sebesar Rp145.650,75 juta 4,91 persen dari total pengeluaran Kabupaten Purworejo. Sedangkan pengeluaran sektor publik yang terendah adalah Kota Pekalongan sebesar Rp137.601,25 berupa pengeluaran bidang pendidikan sebesar Rp105.666,80 juta atau 16,04 persen dari total pengeluaran, dan pengeluaran bidang kesehatan sebesar Rp31.934,45 juta 4,85 persen dari total pengeluaran Kota Pekalongan.

Nilai IPM tertinggi di Provinsi Jawa Tengah pada tahun 2008 sebesar 77,16 yang dicapai oleh Kota Surakarta dan nilai IPM yang terendah sebesar 67,08 yaitu ada di Kabupaten Brebes. Di satu sisi, jumlah penduduk miskin terbanyak di Provinsi Jawa Tengah ada di Kabupaten Brebes yaitu sebanyak 459.300 orang dengan persentase penduduk miskin sebesar 25,98 persen. Sedangkan jumlah penduduk miskin yang paling sedikit ada di Kota Salatiga yang mencapai 14.900 orang dengan persentase penduduk miskin sebesar 8,47 persen. Menurut BPS, terdapat hubungan yang signifikan antara tingkat kualitas pembangunan manusia dengan tingkat kemiskinan. Tabel 4.1. menunjukkan bahwa Kabupaten Brebes di tahun 2008 merupakan kabupaten yang mempunyai tingkat IPM terendah $(67,08)$ sekaligus juga mempunyai jumlah penduduk miskin terbanyak yaitu sebesar 459.300 orang. Hal ini sejalan dengan hasil penelitian yang dilakukan oleh Brata (2005) dan Yani Mulyaningsih (2008) yang menyatakan bahwa tiga dimensi penting dalam pembangunan manusia yang tercakup dalam IPM sangat berpengaruh terhadap kemiskinan. Selengkapnya, hasil statistik deskriptif terhadap variabel penelitian untuk data tahun 2007 dan 2008, dapat dilihat pada Tabel 1. 
Tabel 1. Statistik Deskriptif Variabel Penelitian

\begin{tabular}{|c|c|c|}
\hline Variabel & 2007 & 2008 \\
\hline \multicolumn{3}{|c|}{$\begin{array}{l}\text { Pengeluaran Pemerintah di Pendidikan dan Kesehatan } \\
\text { (juta Rp) }\end{array}$} \\
\hline Mean & $319,588.27$ & $393,876.53$ \\
\hline Minimum & $64,914.63$ & $137,601.25$ \\
\hline Maximum & $498,210.27$ & $799,174.67$ \\
\hline Std. Deviation & $97,713.94$ & $126,523.76$ \\
\hline \multicolumn{3}{|l|}{$\underline{\text { IPM }}$} \\
\hline Mean & 71.09 & 71.57 \\
\hline Minimum & 66.57 & 67.08 \\
\hline Maximum & 76.58 & 77.16 \\
\hline Std. Deviation & 2.36 & 2.34 \\
\hline \multicolumn{3}{|c|}{ Jumlah Penduduk Miskin (ribu) } \\
\hline Mean & 187.34 & 174.93 \\
\hline Minimum & 13.00 & 14.90 \\
\hline Maximum & 492.20 & 459.30 \\
\hline Std. Deviation & 110.83 & 101.41 \\
\hline \multicolumn{3}{|c|}{ Persentase Penduduk Miskin (\%) } \\
\hline Mean & 19.31 & 18.12 \\
\hline Minimum & 5.26 & 6.00 \\
\hline Maximum & 32.29 & 27.87 \\
\hline Std. Deviation & 7.15 & 5.77 \\
\hline
\end{tabular}

\section{Pembahasan}

Hasil yang diperoleh pada uji Moderated Regression Analysis (MRA), menunjukkan bahwa pembangunan manusia yang di-proxy dengan IPM(IPM) bukan merupakan variabel moderating, tetapi merupakan variabel yang berdiri sendiri sebagai variabel prediktor (independen) yang berpengaruh terhadap kemiskinan. Selain itu, pada uji MRA tersebut, ternyata diketahui bahwa variabel pengeluaran pemerintah di sektor pendidikan dan kesehatan (PUB) tidak mempengaruhi kemiskinan (POV). Hasil yang berbeda diperoleh pada saat dilakukan uji interaksi yang digunakan untuk menguji adanya variabel pure moderator (moderator murni), di mana secara statistik ternyata menunjukkan bahwa variabel IPM merupakan variabel pure moderator terhadap variabel kemiskinan (POV). Hal ini mengindikasikan bahwa variabel IPM tidak berfungsi sebagai variabel independen namun langsung berinteraksi dengan variabel independen lainnya (variabel pengeluaran publik/PUB) dalam rangka mengurangi kemiskinan. Dalam uji tersebut, variance variabel kemiskinan (POV) dapat dijelaskan oleh variabel pengeluaran pemerintah di sektor pendidikan dan kesehatan (PUB) dan variabel interaksi antara pengeluaran pemerintah di sektor pendidikan dan kesehatan (PUB) dengan variabel IPM berkisar 40,6 persen sampai dengan 46,4 persen. Namun, pengaruh variabel interaksi terhadap pengurangan kemiskinan masih sangat kecil yaitu berkisar $3,964 \times 10^{-6}$ sampai dengan $5,913 \times 10^{-6}$.

Hasil dari Uji Selisih Nilai Mutlak, menunjukkan bahwa koefisien dari selisih nilai mutlak antara variabel independen (PUB dan IPM) ternyata tidak signifikan. Hal ini berarti bahwa variabel IPM ternyata bukan merupakan variabel moderating. Sama seperti Uji Selisih Nilai Mutlak, dalam Uji Residual juga menunjukkan bahwa variabel IPM bukan merupakan variabel moderating. Hal ini ditunjukkan pada Uji Residual dengan nilai koefisien variabel uji (dalam hal ini variabel kemiskinan) yang negatif namun tidak signifikan. Selengkapnya ikhtisar hasil analisis terhadap hipotesis adanya pengaruh pengeluaran sektor publik secara negatif dan signifikan terhadap angka kemiskinan melalui indikator pembangunan manusia (IPM sebagai variabel moderator), dapat dilihat pada Tabel 2.

Tabel 2. Ikhtisar Analisis Variabel IPM sebagai Variabel Moderator

\begin{tabular}{|l|l|l|}
\hline \multirow{2}{*}{ Uraian } & \multicolumn{2}{|c|}{ Hasil Analisis dengan Data Tahun } \\
\cline { 2 - 3 } & \multicolumn{1}{|c|}{$\mathbf{2 0 0 7}$} & \multicolumn{1}{|c|}{$\mathbf{2 0 0 8}$} \\
\hline Uji dengan MRA & $\begin{array}{l}\text { Variabel IPM bukan merupa-kan variabel } \\
\text { moderator, teta-pi sebagai variabel independen } \\
\text { (prediktor) }\end{array}$ & $\begin{array}{l}\text { Variabel IPM bukan meru-pakan variabel } \\
\text { moderator, tetapi sebagai variabel independen } \\
\text { (prediktor) }\end{array}$ \\
\hline Uji Pure Moderator & $\begin{array}{l}\text { Variabel IPM merupakan variabel pure moderator, } \\
\text { dengan nilai koefisien sebesar }-5,913 \times 10^{-6}\end{array}$ & $\begin{array}{l}\text { Variabel IPM merupakan variabel pure moderator, } \\
\text { dengan nilai koefisien sebesar }-3,964 \times 10^{-6}\end{array}$ \\
\hline Uji Nilai Selisih Mutlak & $\begin{array}{l}\text { Variabel IPM bersama - sama variabel independen } \\
\text { PUB dan IPM mempenga-ruhi variabel kemiskinan } \\
\text { dan pengaruhnya sebesar 49\% }\end{array}$ & $\begin{array}{l}\text { Variabel IPM bersama - sama dengan variabel } \\
\text { PUB mempengaruhi variabel ke-miskinan dan } \\
\text { pengaruhnya sebesar 42,29\% }\end{array}$ \\
\hline Uji Residual & $\begin{array}{l}\text { Variabel IPM bukan merupakan variabel } \\
\text { moderating. }\end{array}$ & $\begin{array}{l}\text { Variabel IPM bukan merupakan variabel } \\
\text { moderating. }\end{array}$ \\
\hline
\end{tabular}

Sumber: Hasil Olahan Data Tahun 2007 dan 2008 dengan Aplikasi SPSS 
Dari uraian tersebut di atas, menunjukkan bahwa IPM tidak bisa berdiri sendiri sebagai variabel independen dalam mempengaruhi tingkat kemiskinan. Hal tersebut mengandung makna bahwa untuk meningkatkan kualitas pembangunan manusia yang di-proxy dengan IPM harus didukung dengan kebijakan pemerintah melalui alokasi sumber pendanaan dari pemerintah daerah maupun pemerintah pusat yang memang ditujukan untuk peningkatan kualitas pembangunan manusia. Kualitas pembangunan manusia, sebagaimana diungkapkan oleh UNDP, terkait dengan aspek pemenuhan kebutuhan akan hidup panjang umur (longevity) dan hidup sehat (healthy life), untuk mendapatkan pengetahuan (the knowledge) dan mempunyai akses kepada sumberdaya yang bisa memenuhi standar hidup.

Dalam berbagai literatur yang ada, menunjukkan bahwa tingkat pembangunan manusia yang tinggi akan mempengaruhi perekonomian melalui peningkatan kapabilitas penduduk yang konsekuensinya adalah pada produktivitas dan kreativitas penduduk. Oleh karena itu, dukungan sumber dana dari pemerintah terutama untuk kegiatan yang berkaitan dengan peningkatan kualitas pembangunan manusia seperti pembangunan bidang pendidikan dan bidang kesehatan, sangat menentukan dalam peningkatan kualitas pembangunan manusia yang ujungnya adalah pertumbuhan ekonomi dan kesejahteraan. (Aloysius Gunadi Brata, 2002).

Walaupun IPM berpengaruh terhadap kemiskinan sebagai variabel yang memperkuat/memperlemah variabel independen lainnya (sebagai variabel pure moderating), namun pengaruhnya masih sangat kecil. Kecilnya pengaruh interaksi tersebut, bisa disebabkan karena rendahnya alokasi pengeluaran sektor publik dari pemerintah kabupaten/kota yang ada di Provinsi Jawa Tengah.

Data statistik dari BPS menunjukkan bahwa, rata-rata persentase alokasi pengeluaran pemerintah sektor publik bidang pendidikan pada 35 kabupaten/ kota yang ada di Provinsi Jawa Tengah pada tahun
2007 hanya sebesar 4,91 persen dan pada tahun 2008 sebesar 5,41 persen. Sedangkan rata-rata persentase alokasi pengeluaran pemerintah sektor publik bidang kesehatan pada 35 kabupaten/kota yang ada di Provinsi Jawa Tengah pada tahun 2007 hanya sebesar 1,27 persen dan pada tahun 2008 sebesar 1,37 persen. Hal ini menunjukkan bahwa meskipun kecenderungan adanya peningkatan pengeluaran pemerintah sektor publik, namun karena masih minimnya alokasi dana tersebut menyebabkan belum adanya pengaruh pengeluaran tersebut terhadap kemiskinan dan jika diinteraksikan dengan variabel pembangunan manusia (IPM), pengaruhnya masih sangat kecil.

Menurut Agus Salim (2007), pengeluaran pemerintah di sektor pendidikan dan kesehatan, baik secara langsung maupun tidak langsung, merupakan suatu kebijakan yang pro poor yang mempunyai dampak yang negatif terhadap kemiskinan melalui dampaknya terhadap pertumbuhan dan pemerataan. Di samping itu, kebijakan pengeluaran tersebut mempunyai pengaruh positif terhadap pertumbuhan melalui dampaknya terhadap pembentukan modal manusia (human capital). Kebijakan inilah yang yang dianggap sebagai kebijakan yang berdampak ganda (win win policies).

Selain itu, hasil analisis terhadap pengaruh pengeluaran sektor publik secara negatif dan signifikan terhadap angka kemiskinan yang diperkuat dengan indikator pembangunan manusia (IPM sebagai variabel intervening), dapat diikhtisarkan seperti pada Tabel 3.

Sejalan dengan hasil analisis yang menyatakan bahwa IPM merupakan variabel pure moderator yang tidak berhubungan dengan variabel kemiskinan dan variabel pengeluaran sektor publik, namun berinteraksi dengan variabel pengeluaran publik dalam mempengaruhi kemiskinan, maka hasil analisis seperti dalam Tabel 4.3. tersebut menyatakan bahwa pada tahun 2008 variabel IPM merupakan variabel intervening yang ikut mempengaruhi hubungan antara variabel independen (pengeluaran sektor publik) dengan

Tabel 3.Ikhtisar Analisis Variabel IPM sebagai Variabel Intervening (Mediating)

\begin{tabular}{|l|l|l|}
\hline \multirow{2}{*}{ Uraian } & \multicolumn{2}{|c|}{ Hasil Analisis dengan Data Tahun } \\
\cline { 2 - 3 } & \multicolumn{1}{|c|}{$\mathbf{2 0 0 7}$} & \multicolumn{1}{c|}{$\mathbf{2 0 0 8}$} \\
\hline \multirow{4}{*}{ Uji analisis jalur dan Uji Sobel } & Variabel Indeks Pemba-ngunan Manusia & Variabel Indeks Pemba-ngunan Manusia (IPM) \\
& (IPM) bukan merupakan variabel & merupakan variabel intervening, karena nilai t \\
& intervening, karena nilai t hitung $=$ & hitung = 4,9367 lebih besar dari nilai t tabel $=$ \\
& 0,53434 kurang dari nilai t tabel $=1,96$. & 1,$96 ;$ dengan total pengaruh sebesar 5,9732 x $10^{-6}$ \\
\hline
\end{tabular}

Sumber: Hasil Olahan Data Tahun 2007 dan 2008 dengan Aplikasi SPSS 
variabel dependen (kemiskinan). Namun pada tahun 2007 hasil pengujian hipotesis menunjukkan bahwa variabel IPM bukan merupakan variabel intervening. Hal tersebut terlihat dari nilai thitung $=0,53434$ kurang dari nilai $\mathrm{t}$ tabel $=1,96$ pada tingkat signifikansi $\alpha=0,05$.

Perbedaan hasil uji intervening antara tahun 2007 dan 2008 tersebut, disebabkan karena adanya peningkatan pengeluaran sektor publik yang cukup signifikan dimana pada tahun 2008, secara total untuk 35 kabupaten/kota yang ada di Provinsi Jawa Tengah menunjukkan peningkatan pengeluaran sektor publik sebesar Rp2.600.089,42 juta atau terjadi peningkatan sebesar 23,24 persen jika dibandingkan dengan tahun 2007. Sumbangan terbesar terjadi pada pengeluaran sektor publik bidang pendidikan, yaitu meningkat sebesar Rp2.163.143,18 juta pada tahun 2008 atau terjadi kenaikan sebesar 24,14 persen jika dibandingkan dengan tahun 2007. Sedangkan kenaikan pengeluaran sektor publik bidang kesehatan pada tahun 2008 sebesar Rp436.946,24juta atau naik sebesar 19,64 persen jika dibandingkan dengan tahun 2007.

Adanya perbedaan hasil uji intervening tersebut, juga ditandai dengan semakin meningkatnya persentase pengeluaran sektor publik terhadap PDRB pada masing-masing kabupaten/kota yang ada di Provinsi Jawa Tengah. Rata-rata persentase pengeluaran sektor publik terhadap PDRB di 35 kabupaten/kota di Provinsi Jawa Tengah, pada tahun 2007 mencapai 6,19 persen dan pada tahun 2008 meningkat sebesar 0,69 persen menjadi 6,78 persen. Sumbangan terbesar peningkatan persentase pengeluaran sektor publik terhadap PDRB tersebut terjadi pada bidang pendidikan, di mana secara rata-rata persentase pengeluaran bidang pendidikan terhadap PDRB pada tahun 2008 meningkat sebesar 0,50 persen menjadi 5,41 persen jika dibandingkan tahun 2007 yang mencapai 4,91 persen. Sedangkan persentase pengeluaran bidang kesehatan terhadap PDRB pada tahun 2008 meningkat 0,10 persen menjadi 1,37 persen dari tahun 2007 yang mencapai 1,27 persen.

Adanya pengaruh intervening pada variabel indeks pembangunan manusia, mengandung arti bahwa pengeluaran pemerintah sektor publik tidak akan serta merta langsung berpengaruh terhadap pengurangan kemiskinan, namun pengaruhnya dapat dirasakan jika pengeluaran tersebut berkaitan dengan peningkatan kualitas pembangunan manusia seperti pengeluaran bidang pendidikan dan kesehatan. Namun demikian, total pengaruh variabel IPM sebagai variabel yang memediasi hubungan antara pengeluaran pemerintah sektor publik terhadap pengurangan kemiskinan masih sangat kecil yaitu pada tahun 2008 hanya sebesar $5,9732 \times 10^{-6}$.

Hasil analisis tersebut di atas, yang menyatakan bahwa variabel pengeluaran pemerintah sektor publik tidak berpengaruh secara langsung terhadap pengurangan kemiskinan, juga terbukti dalam studi yang dilakukan oleh Yani Mulyaningsih (2008). Dalam penelitian tersebut menunjukkan bahwa alokasi pengeluaran pemerintah tidak berpengaruh terhadap peningkatan pembangunan manusia yang di-proxy dari indeks pembangunan manusia, dan juga tidak berpengaruh terhadap kemiskinan. Salah satu penyebabnya adalah karena masih rendahnya pengeluaran pemerintah di sektor publik terutama untuk sektor pendidikan dan kesehatan.

Pembangunan manusia, yang dalam penelitian ini di-proxy dengan IPM, secara statistik mempunyai pengaruh terhadap kemiskinan sebagai variabel pure moderating yang memperkuat atau memperlemah hubungan antara variabel independen yaitu variabel pengeluaran pemerintah sektor publik (PUB) terhadap variabel dependen yaitu variabel Kemiskinan (POV), di mana variabel pembangunan manusia (IPM) tidak berhubungan dengan variabel dependen dan variabel independen, namun variabel pembangunan manusia berinteraksi dengan variabel independen (pengeluaran sektor publik). Selain itu, variabel IPM juga sebagai variabel intervening (pada tahun 2008) yaitu variabel yang ikut mempengaruhi hubungan antara variabel independen (variabel pengeluaran pemerintah sektor publik) dan variabel dependen (variabel kemiskinan).

Secara umum, hasil penelitian menunjukkan bahwa apabila pengeluaran pemerintah tidak ditujukan untuk meningkatkan kualitas pembangunan manusia, maka pengentasan kemiskinan tidak akan terwujud. Secara logis hal ini bisa dikaitkan dengan jangkauan pelayanan pendidikan dan kesehatan kepada masyarakat miskin, di mana jika pelayanan pendidikan maupun kesehatan kepada masyarakat terutama masyarakat miskin semakin tidak terjangkau, maka kemiskinan akan terus meningkat. Hal tersebut disebabkan karena penduduk miskin yang sakit dan tidak mampu berobat karena layanan kesehatan yang rendah dan minimnya pengetahuan dari pasien yang bersangkutan untuk menghindari penyakit tersebut, maka secara otomatis dia tidak akan mampu memenuhi ke- 
butuhan dasar dirinya sendiri bahkan mungkin keluarganya. Lingkaran setan inilah yang menyebabkan sulitnya pemerintah dalam mengurangi kemiskinan, terutama jika kebijakan pemerintah yang dijalankan bukan kebijakan yang pro poor. Hal ini tercermin dari masih minimnya alokasi dana pemerintah yang digunakan untuk peningkatan kualitas pembangunan manusia.

Menurut Novianto (2003), esensi utama dari masalah kemiskinan adalah masalah aksesibilitas. Aksesibilitas berarti kemampuan seseorang atau sekelompok orang dalam masyarakat untuk mendapatkan sesuatu yang merupakan kebutuhan dasarnya dan seharusnya menjadi haknya sebagai manusia dan sebagai warga negara. Seseorang atau sekelompok orang yang miskin, mempunyai daya aksesibilitas yang rendah dan terbatas terhadap berbagai kebutuhan dan layanan dibandingkan mereka yang termasuk golongan menengah ataupun golongan kaya. Akses-akses yang tidak bisa didapat oleh masyarakat miskin yaitu: 1) akses untuk mendapatkan makanan yang layak, 2) akses untuk mendapatkan sandang yang layak, 3) akses untuk mendapatkan rumah yang layak, 4) akses untuk mendapatkan layanan kesehatan, 5) akses untuk mendapatkan layanan pendidikan, 6) akses kepada leisure dan entertainment, dan 7) akses untuk mendapatkan kualitas hidup yang layak.

Untuk mengatasi masalah kemiskinan, peranan pemerintah dalam meningkatkan kualitas pembangunan manusia sangat besar diharapkan. Investasi pemerintah untuk pembangunan manusia, baik itu di bidang pendidikan dan kesehatan ataupun bidang lainnya yang berkaitan dengan pelayanan publik, merupakan suatu kegiatan yang berkaitan dengan bidang ekonomi. Meningkatnya kesehatan dan pendidikan akan mendorong peningkatan produktivitas tenaga kerja, dan pada gilirannya akan meningkatkan pendapatan anggota masyarakat. Dengan demikian, semakin besar investasi pembangunan manusia akan berdampak pada semakin tinggi produktivitas dan pendapatan individual, regional dan nasional serta merupakan aspek pendorong peningkatan pertumbuhan ekonomi.

Menurut data statistik BPS yang berkaitan dengan indikator pembangunan manusia yang ada di kabupaten/kota di Provinsi Jawa Tengah, yaitu IPM dan indikator yang membentuk IPM seperti Angka Harapan Hidup, Angka Melek Huruf, Rata-rata Lama Sekolah, dan Pengeluaran Riil per Kapita, terlihat bahwa rata-rata di 35 kabupaten/kota di Provinsi Jawa Tengah menunjukkan kecenderungan yang meningkat. Capaian IPM rata-rata untuk 35 kabupaten/kota di Provinsi Jawa Tengah pada tahun 2008 sebesar 71,6 atau meningkat sebesar 0,67 persen jika dibandingkan dengan rata-rata capaian tahun 2007 sebesar 71,1. Peningkatan capaian indikator pembangunan manusia ini menunjukkan semakin baiknya kualitas pembangunan manusia di 35 kabupaten/kota yang ada di Provinsi Jawa Tengah.

Peningkatan kualitas pembangunan pada 35 kabupaten/kota di Provinsi Jawa Tengah tersebut diikuti dengan indikator kemiskinan yang menunjukkan kecenderungan yang menurun. Menurut data statistik BPS, indikator jumlah penduduk miskin maupun persentase penduduk miskin yang ada di 35 kabupaten/kota di Provinsi Jawa Tengah, terus menurun dari tahun 2007 persentase penduduk miskin di Provinsi Jawa Tengah sebesar 20,43 persen dan pada tahun 2008 persentase penduduk miskin turun sebesar 7,05 persen atau menjadi 18,99 persen. Hal ini sejalan dengan hasil penelitian bahwa indikator pembangunan manusia akan mempengaruhi indikator kemiskinan secara signifikan dan negatif sebagai variabel pure moderating maupun sebagai variabel intervening. Namun demikian, pengaruh variabel IPM sebagai variabel pure moderating maupun variabel intervening terhadap hubungan antara pengeluaran sektor publik dengan kemiskinan, masih sangat kecil. Hal ini merupakan keterbatasan studi ini, karena studi ini lebih menekankan kepada political will dari pemerintah kabupaten/kota di Provinsi Jawa Tengah dalam mengurangi kemiskinan yang dilihat dari kebijakan pengeluaran sektor publik yang berkaitan dengan peningkatan kualitas pembangunan manusia yaitu pengeluaran bidang pendidikan dan kesehatan

\section{KESIMPULAN DAN SARAN}

\section{Kesimpulan}

Berdasarkan hasil pembahasan yang telah diuraikan pada bagian sebelumnya, maka dapat diambil beberapa kesimpulan sebagai berikut:

- Hasil studi menunjukkan bahwa alokasi pengeluaran pemerintah sektor publik tidak secara langsung mempengaruhi IPM ataupun kemiskinan, namun secara bersama-sama (simultan) pengeluaran sektor publik dan IPM dapat mempengaruhi 
kemiskinan. Hal tersebut berarti bahwa pengeluaran pemerintah di sektor pendidikan dan kesehatan tidak bisa berdiri sendiri sebagai variabel independen dalam mempengaruhi kemiskinan, namun harus berinteraksi dengan variabel lain (variabel IPM). Hal ini juga diperkuat dengan hasil studi yang menunjukkan bahwa selain berperan sebagai variabel pure moderator, IPM juga berperan sebagai variabel intervening (tahun 2008), dalam kaitannya dengan hubungan antara pengeluaran di sektor pendidikan dan kesehatan dengan pengentasan kemiskinan. Sehingga implikasi dari hasil penelitian ini menunjukkan bahwa pengeluaran pemerintah di sektor pendidikan dan kesehatan akan dapat mempengaruhi kemiskinan jika pengeluaran tersebut dilakukan dalam rangka peningkatan kualitas pembangunan manusia.

- Adanya perbedaan hasil uji intervening untuk data tahun 2007 dan 2008, di mana pada tahun 2008 variabel IPM berperan sebagai variabel intervening, sedangkan pada tahun 2007 variabel IPM tidak berperan sebagai variabel intervening, disebabkan karena adanya peningkatan pengeluaran sektor publik yang cukup signifikan yang terjadi pada 35 kabupaten/kota di Provinsi Jawa Tengah, di mana pada tahun 2008 secara total terjadi peningkatan sebesar 23,24 persen jika dibandingkan dengan tahun 2007, serta karena adanya peningkatan persentase rata-rata pengeluaran sektor publik terhadap PDRB masing-masing kabupaten/kota di Provinsi Jawa Tengah sebesar 0,69 persen.

- Indikator IPM menunjukkan kecenderungan peningkatan, di mana capaian IPM rata-rata untuk 35 kabupaten/kota di Provinsi Jawa Tengah pada tahun 2008 meningkat sebesar 0,67 persen jika dibandingkan dengan rata-rata capaian tahun 2007. Peningkatan kualitas pembangunan manusia tersebut diikuti dengan indikator kemiskinan yang menunjukkan kecenderungan yang menurun. Di mana, persentase penduduk miskin di Provinsi Jawa Tengah pada tahun 2008, turun sebesar 7,05 persen menjadi 18,99 persen jika dibandingkan tahun 2007.

\section{Saran}

Adapun saran-saran yang dapat diberikan dalam penelitian ini adalah sebagai berikut:

- Berdasarkan hasil penelitian diketahui bahwa pembangunan manusia yang tercermin dari nilai IPM akan berpengaruh terhadap pengurangan kemiskinan, baik itu sebagai variabel pure moderator maupun sebagai variabel intervening. Hal tersebut mengindikasikan bahwa IPM merupakan variabel yang dapat mempengaruhi variabel kemiskinan (sebagai variabel dependen) jika berinteraksi dengan variabel independen lainnya. Selain itu, variabel IPM juga merupakan variabel yang memediasi variabel independen lainnya dalam mempengaruhi variabel kemiskinan. Oleh karena itu, dalam rangka mengurangi kemiskinan sangat diperlukan dukungan kebijakan dari pemerintah kabupaten/kota di Provinsi Jawa Tengah untuk meningkatkan kualitas pembangunan manusia (IPM) di daerahnya. Beberapa hal yang bisa dilakukan oleh pemerintah kabupaten/kota di Provinsi Jawa Tengah untuk meningkatkan IPM, salah satunya terkait dengan pengeluaran pemerintah untuk sektor publik dalam rangka penyediaan kapasitas dasar seperti pendidikan dan kesehatan bagi masyarakatnya, terutama masyarakat miskin. Keberpihakan pengeluaran pemerintah untuk mengurangi kemiskinan (pro poor fiscal policy) sangat penting untuk dilakukan oleh pemerintah daerah.

- Studi ini, menunjukkan adanya keterkaitan IPM sebagai variabel pure moderator maupun sebagai variabel intervening (mediating) terhadap hubungan antara pengeluaran publik dan kemiskinan, namun pengaruhnya masih sangat kecil. Pengaruh variabel IPM sebagai variabel pure moderator pada tahun 2007 sebesar $-5,913 \times 10^{-6}$ dan pada tahun 2008 sebesar $-3,964 \times 10^{-6}$. Sedangkan total pengaruh variabel IPM sebagai variabel interven-

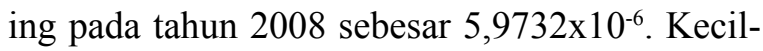
nya pengaruh tersebut dikarenakan keterbatasan dari studi ini, di mana variabel independen yang mempengaruhi variabel kemiskinan baru sebatas pada political will pemerintah kabupaten/kota dalam mengurangi kemiskinan yang dilihat dari kebijakan pengeluaran sektor publik yang berkaitan dengan peningkatan kualitas pembangunan manusia berupa pengeluaran bidang pendidikan dan kesehatan. Dengan demikian, perlu dilakukan penelitian lanjutan mengenai keterkaitan variabel-variabel lain termasuk variabel IPM terhadap variabel kemiskinan. 


\section{DAFTAR PUSTAKA}

Abdul Hakim. 2001. Ekonomi Pembangunan. UII Press. Yogyakarta.

Agusalim. 2007. Peran Anggaran Pemerintah Terhadap Pengurangan Angka Kemiskinan di Indonesia. Ekonomi dan Bisnis. Vol. 10 No. 1.

BPS. 2009. Data dan Informasi Kemiskinan 2004. Data dan Informasi Kemiskinan 2002. Data dan Informasi Kemiskinan Statistik Keuangan Daerah Kabupaten dan Kota Berbagai Publikasi

. Jawa Tengah Dalam Angka Tahun 2006

. Jawa Tengah Dalam Angka Tahun 2007

. Jawa Tengah Dalam Angka Tahun 2008

Jawa Tengah Dalam Angka Tahun 2009

2009. Indikator Utama Sosial, Politik dan Keamanan Provinsi Jawa Tengah 2008.

Brata, Aloysius Gunadi. 2005. Investasi Sektor Publik Lokal, Pembangunan Manusia, dan Kemiskinan. Lembaga Penelitian - Universitas Atma Jaya Yogyakarta, Februari

Chemingui, Mohamed Abdelbasset. 2007. Public Spending and Poverty Reduction in an Oil based Economy: The Case of Yemen. Revised: January

Damodar Gujarati. 1991. Ekonometrika Dasar, Terjemahan oleh Sumarno Zain. Penerbit Erlangga, Jakarta.

Fan, Shenggen. 2000. How Does Public Spending Affect Growth and Poverty? The Experience of China. Paper submitted to 2nd annual Global Development Network Confrence. Tokyo, Japan.

Guritno Mangkoesoebroto. 2001. Ekonomi Publik, BPFE UGM, Yogyakarta

Gomanee, Karuna. 2003. Aid, Public Spending and Human Welfare: Evidence From Quantile Regressions, Paper for a Session on 'Poverty and Human Development'. Organised by Dr Noorbakhsh at the DSA Annual Conference. Glasgow. 10-12 September

Insukindro, R. Maryatmo, Aliman, Sri Yani Kusumastuti, A. Ika Rahutami. 2004. Modul Ekonometrika Dasar. Kerjasama BI dan FE UGM. Yogyakarta.

Imam Ghozali. 2009. Ekonometrika: Teori, Konsep dan Aplikasi dengan SPSS 17. Badan Penerbit Universitas Diponegoro, Semarang.
Jhingan, ML. 2000. Ekonomi Pembangunan dan Perencanaan. Edisi Pertama. Raja Grafindo Persada. Jakarta.

Lincolin Arsyad. 1999. Ekonomi Pembangunan. Edisi Keempat, Bagian Penerbitan STIE YKPN. Yogyakarta.

Mahmudi. 2007. Manajemen Kinerja Sektor Publik. UPP STIM YKPN. Yogyakarta.

Mudrajad Kuncoro. 2000. Ekonomi Pembangunan: Teori, Masalah, dan Kebijakan. UPP AMP YKPN. 2004. Otonomi dan Pembangunan Daerah: Reformasi, Perekonomian, Strategi dan Peluang. Penerbit Erlangga. Jakarta.

Musgrave, Richard. A dan Peggy B Musgrave. 1989. Public Finance in Theory and Practise. Fifth Edition, McGraw-Hill Book, International Edition, 1989.

Novianto Dwi Wibowo. 2003. Masalah Pengentasan Kemiskinan di Indonesia: Pendekatan Hipotesis Kuznet. Buletin Pangsa. Edisi 10/IX.

Priyo Hari Adi, Fhino Andrea Christy. 2009. Hubungan antara Dana Alokasi Umum, Belanja Modal dan Kualitas Pembangunan Manusia. The $3^{\text {rd }}$ National Conference UKWMS. Surabaya.

Sadono Sukirno. 2000. Makroekonomi Modern. Raja Grafindo Persada. Jakarta.

Stigliz, E. Joseph. 1986. Economic of Public Sector. New York: WW Norton and Company

Syaukani, H.R, Affan Gaffar, Ryass Rasyid. 2005. Otonomi Daerah dalam Negara Kesatuan Republik Indonesia. Pustaka Pelajar. Cetakan ke IV. Yogyakarta.

Todaro, Michael. (2000). Pembangunan Ekonomi di Dunia Ketiga. Edisi ke-7 (Terjemahan Bahasa Indonesia). Jakarta. PT Erlangga.

UNDP. 1990. Human Development Report . 1997. Human Development Report 2005. Human Development Indicator

World Bank. 2007. Ikhtisar Kajian Pengeluaran Publik Indonesia: Memaksimalkan peluang Baru: Kajian Pengeluaran Publik Indonesia. Februari.

Zuluaga. 1990. Different Channels of Impact of Education on Poverty: An Analysis for Colombia. Preliminary Draft. 